\title{
O.В. Смірнова
}

Харківський національний університет міського господарства імені О.М. Бекетова, Украӥна

\section{ПРИНЦИПИ ФОРМУВАННЯ АРХІТЕКТУРНОГО СЕРЕДОВИЩА ІННОВАЦЙНИХ НАУКОВО-ВИРОБНИЧИХ ОБ'СКТІВ}

\begin{abstract}
Стаття присвячена виявленню особливостей проектування інноваційних науково-виробничих об'єктів з метою розробки методологічних основ їх формування. У статті викладено критерії формування, приведено основну диференціаџію та виявлено типологічну структуру інноваџійних науково-виробничих об'єктів. Розроблено чіткий понятійний апарат. Дано визначення поняттю «інноваційні науково-виробничі об'єкти». Сформульовано основні принципи архітектурного вдосконалення структури інноваційних наукововиробничих об'єктів.
\end{abstract}

Ключові слова: інновації, науково-виробничі об'єкти, диференціація, принциипи.

\section{Постановка проблеми}

Інноваційні науково-виробничі об'єкти є особливим архітектурним середовищем, призначеним для ведення інноваційної науково-виробничої діяльності з відповідною інфраструктурою (IHBO).

В кінці 1960-70-х рр. в світі розширюється інноваційна діяльність; дослідження, розробка і впровадження нововведень стає невід'ємною частиною великого бізнесу. Початок цьому процесу поклало зародження і розвиток в 1950-і рр. в США територіальних науково-виробничих утворень інноваційного спрямування, що до сих пір служать моделями створення подібних структур у всьому світі. У країнах-лідерах в області інновацій процес створення IHBO йде наростаючими темпами (в США число інноваційних об'єктів обчислюється тисячами, в Великобританії і Німеччині - сотнями), що свідчить про актуальність вивчення особливостей формування інноваційних науково-виробничих об'єктів.

Таким чином, актуальним $є$ питання формування наукового підходу до проектування архітектурного середовища інноваційних наукововиробничих об'єктів. Своєчасною стає розробка науково-обгрунтованих рекомендацій та принципів, що дозволять фахівцям вирішувати питання ефективного формування науково-виробничих об’єктів 3 використанням сучасних технологій.

\section{Аналіз останніх досліджень і публікацій}

Наукових досліджень 3 даної проблематики фактично немає, а наукові публікації носять постановчий характер. [1-4]

Мета статті - визначити принципи формування інноваційних науково-виробничих об'єктів.

Завдання дослідження:
1. Виявити критерії диференціації та визначити типи сучасних інноваційних науково-виробничих об'єктів.

2. Визначити принципи формування архітектурного середовища інноваційних наукововиробничих об'єктів.

\section{Виклад основного матеріалу}

IHBO - новий тип архітектурного середовища, що виник у відповідь на потреби сучасної глобальної економіки знань, адаптований до умов швидких змін економічних і суспільних відносин. Серед найбільш поширених технологій, напрямків діяльності і послуг IHBO - інформаційні, телекомунікаційні, комп'ютерні та інтернет-технології, нано- та біотехнології; фармацевтика; медицина; хімія; оптика; нові матеріали; фундаментальні дослідження; промислові / виробничі системи; промислова електроніка; машинобудування; аеронавтика / космонавтика; побутова техніка; енергетика; харчові та с/г технології, екологія (природокористування) тощо.

Широкий спектр інноваційної діяльності, функціональні і територіальні аспекти розвитку IHBO визначають їх типологічну різноманітність - від окремого будинку, групи будинків - до великих територіальних комплексів. [5] Формування загальної концепції IHBO, їх функціональної структури, архітектурно-просторової композиції, об'ємнопланувальних, конструктивних, образних рішень залежать від ряду містобудівних і технологічних особливостей їх формування.

Містобудівні особливості пов'язані 3 місцем IHВО в структурі міської агломерації і включають: фактори розміщення, розмір території, вплив природного ландшафту, умови будівництва. Високі вимоги до екології робочого середовища виводять фактор впливу природного ландшафту в розряд виріша- 
льних, обумовлюючи бажаність розміщення поблизу зелених масивів, парків, рекреаційних зон, як частини благоустрою ІНВО. За умовами будівництва при створенні IHBO можна використовувати нове будівництво, реконструкцію існуючого фонду площ. Залежно від умов власності IHBO поділяються на власні об'єкти («резиденти») і на об'єкти, призначені для здачі в тимчасове користування на комерційній основі. Визначено, що розмір компаній, що беруть приміщення в тимчасове користування, впливає на архітектурне формування IHBO (передбачається поділ на окремі блоки; в оренду здаються малі (15-200 м²), середні (200-600 м²), великі (600-2000 $\mathrm{M}^{2}$ ) приміщення (модулі).

Розглянуті особливості організації IHBO формують основу їх функціонально-планувальної та архітектурної організації. Організація конкретного типу IHBO включає розробку архітектурнопросторової композиції об'єкта з чітким визначенням кількості будівель із займаною площею і розмірів ділянки. Слід зазначити, що можливе застосування різних компонувальних схем: з окремих будівель; з будівель, зблокованих в компактні обсяги; 3 будівель, зблокованих уздовж загальної комунікаційної галереї. Вибір компонувальної схеми залежить від особливостей технології, обмежень генерального плану, економіки, творчих позицій.

Слід дотримуватися чіткого зонування на всіх просторових рівнях (генерального плану, будівлі, приміщення); виділення зон - робочої, інженернотехнічної, соціальної (відкритого і закритого доступу), з урахуванням перспективного розширення комплексу; при необхідності - застосування прийомів вертикального зонування.

Проведений аналіз формування об'ємнопросторової структури IHBO дозволяє викласти основні критерії їх диференціації:

- за переважним видом діяльності - об'єкти індустріальні, технологічні, ділові, наукові;

- за профілем діяльності - об'єкти, де проводяться дослідження в одній або декількох областях;

- за площею - фізичні розміри будівель (загальна площа і розміри ділянки);

- за особливостями об'ємно-просторової організації - окрема будівля, група будівель, архітектурно-містобудівний комплекс;

- за розміщенням в межах міської агломерації центр міста, міська периферія, заміські райони;

- за характером забудови - 3 компактним розміщенням будівель, 3 фронтальною і розосередженою формою розміщенням будівель;

- за умовами будівництва та власності - нове будівництво, реконструкція; об'єкти власні або призначені для здачі в тимчасове користування;

- за рівнем територіальної організації: об'єкт, зона, наукоград (поєднання навчальних, наукових, конструкторсько-технологічних, дослідновиробничих підприємств 3 розвиненою мережею соціально-побутового та інформаційно-культурного обслуговування);

- за типом базового підприємства - об'єкти при вузі, науково-дослідному інституті, промисловому підприємстві тощо.

3 урахуванням викладених критеріїв диференціації слід виділити чотири типи цих об'єктів:

Інноваційний центр - суб'єкт інноваційної інфраструктури, що здійснює спільні дослідження 3 фірмами, перепідготовку та підвищення кваліфікації кадрів, що вивчають основи інновації і організують нові комерційні компанії, які фінансують на стадії їх становлення.

Бізнес-інкубатор - багатофункціональний комплекс, що забезпечує сприятливі умови для ефективної діяльності новоутворених малих інноваційних підприємств, що реалізують цікаві наукові ідеї. Він є своєрідним симбіозом малих фірм-новаторів 3 іншими суб'єктами на комерційних засадах.

Технопарк - суб'єкт інноваційної інфраструктури із сприятливими умовами для розвитку підприємництва в науково-технічній сфері при наявності оснащеної інформаційної та експериментальної бази i високою концентрацією кваліфікованих кадрів. Технопарк є формою територіальної інтеграції науки, освіти і виробництва.

Технополіс - суб'єкт інноваційної інфраструктури, що спеціалізується на прикладних дослідженнях і розробках з метою комерціалізації їх результатів. Науково-експериментальна і соціальнокультурна інфраструктура, об'єднана навколо наукового центру і призначена для підтримки самостійних малих науково-технічних організацій і окремих учених в справі впровадження результатів НДР в нову техніку, технологію і поширенню їх на ринку.

В цілому сучасні високоефективні IHBO - це якісно нова структура, яка об'єднує безліч функцій і напрямків: дослідження, розробки, дослідне виробництво, маркетинг, інформаційне та культурнопобутове обслуговування, освіту, відпочинок. [6] Архітектурно-просторове формування IHBO слідує загальноприйнятим закономірностям створення сучасних об'єктів громадського, наукового та виробничого призначення. Однак ряд положень є характерними для IHBO як для самостійного, складного об'єкта проектування. Тому формування IНВО слід здійснювати з урахуванням виявлених принципів.

Принцип інтеграції та реструктуризації повинен забезпечити інтегрування будівель і споруд в архітектурно-містобудівну, науково-дослідну, виробничу і соціокультурну підсистеми. Він дозволяє поліпшити здійснення основних процесів інноваційної діяльності людей за рахунок прийомів інтеграції та реструктуризації основних об'єктів, в разі необ- 
хідності здійснити їх функціональне наповнення за рахунок його ущільнення (включення нових функцій, перепланування приміщень). Динамічність процесів інноваційної науково-виробничої діяльності вимагає постійної зміни інфраструктури об'єкта. Специфіка інноваційного процесу і його результатів передбачає можливість розширення і зміни його складових, що вимагає наявності додаткової площі. 3 цією метою здійснюється створення додаткової території для розширення зон і об'єктів комплексу всіх призначень: робочої, соціальної, інженерної, допоміжної, автостоянок. Створення додаткового фонду об'єктів, різноманітних по просторовим параметрам, готових приймати нові колективи дослідників; забезпечення можливості нарощування комунікацій; розширення спектра послуг для співробітників і створення додаткових пов'язаних з цим просторів; забезпечення резервів конструктивної несучої здатності з урахуванням зміни корисних навантажень, пов'язаних зі зміною технології. Принцип інтеграції та реструктуризації забезпечує безперебійне в часі і надійне з точки зору інноваційної ефективності функціонування IНВО.

Принцип структурного модульного формування дає можливість швидко реагувати на зміни вимог ринку - одне з найважливіших умов успішної інноваційної діяльності. Гнучкість і здатність до трансформації визначають універсальність рішень IHВО. У зв'язку 3 короткими (2-3 роки) строками оновлення обладнання в інноваційному процесі необхідно забезпечення умов для роботи колективів i технологій, що вимагає створення універсальних просторів. Одним 3 критеріїв оцінки проектного рішення є ступінь пристосованості до змін, що відбуваються з часом в експлуатації об'єкта в зв'язку з вимогами персоналу і технології. У структурному формоутворенні будівель IHBO слід застосовувати:

- Функціональну диверсифікацію - збільшення видів функціонального використання будівель;

- Варіативність - збільшення числа варіантів планувальних рішень для кожної будівлі;

- Модульність - взаємозамінність функціонально-планувальних компонентів будівель;

- Автономність - можливість підведення комунікацій до кожного модулю будівлі;

- Дискретність - прийом побудови від часткового до загального, при якому спільне компонування функціонально планувальних елементів утворює більші адаптивні планувальні модулі.

Виявлено узагальнені види просторів 3 групами параметрів, універсальними для певної інноваційної діяльності та застосування відповідних модулів:

- для експериментальних процесів, пов'язаних 3 роботою на великогабаритному обладнанні - сітки $(12-24) *(6-18)$, висоти 4,8-10 м;
- для процесів загально лабораторного типу, пов'язаних 3 роботою на лабораторному устаткуванні - сітки (9-12)*(9-12), висоти 3,6-6 м;

- для процесів офісного типу, пов'язаних з роботою на комп’ютері - сітки (6-9)*(6-9), висоти 3,34,2 м.

Усередині кожної групи параметрів гнучкість і трансформованість простору може досягатися за допомогою мобільних перегородок, кабін-«боксів», інвентарних стелажних конструкцій та інших планувальних засобів. Початкове закладення якостей структурного і модульного формоутворення в будівлях і просторові рішення IНВО веде до підвищення одноразової вартості їх будівництва, але знижує згодом вартість робіт з перепланування.

Принцип екологічної стійкості та безпеки спрямований на формування комфортного середовища в інтер'єрних і екстер'єрних просторах. Будівництво споруд їх експлуатація і утилізація відходів не повинні завдавати шкоди навколишньому середовищу. При енергозабезпеченні будинків слід обмежити використання невідновлюваних джерел енергії. При виборі матеріалу слід віддавати перевагу місцевим матеріалами. Конструктивні деталі будівель повинні передбачати легку утилізацію і сортування відпрацьованих матеріалів в кінці терміну служби будівель, щоб можна було повторно їх використовувати. Необхідна мінімізація використання існуючих централізованих зовнішніх енергосистем, де енергоносієм є вуглеводневе паливо; максимально слід використовувати автономні або локальні системи і технічні пристрої на основі альтернативних джерел енергії, які забезпечують тепловою і електричною енергією будівлі або групи будівель.

Вибір енергосистеми таких будівель залежить від місцевих природних умов і наявності центральних енергосистем і газопостачання. Особлива увага повинна приділятися природним компонентам на території IНВО. Необхідно застосування мобільних систем озеленення і максимальне збереження існуючої природного середовища. Важливо забезпечити поєднання в IHBO зон обмеженого доступу і зон, відкритих для широкого кола відвідувачів. Необхідність забезпечення охорони інтелектуальної і фізичної власності, персональної безпеки, захисту від надзвичайних ситуацій - передбачає забезпечення комплексу організаційних заходів, створення об'єктів і зон недоступності для сторонніх, автономних входів, відсіків; велика кількість засклених перегородок всередині. Разом з тим підвищується цінність поняття «відкритість» як життєво необхідної для категорії інновацій. Вільне переміщення інформації як основне завдання функціонування i розвитку сучасних компаній. Успішний i стійкий 
IHВО повинен забезпечувати можливість прямого діалогу з клієнтом, гнучкість, відкритість.

Принцип соціокультурної і естетичної активізації спрямований на створення комфортного соціального середовища, що вимагає об'єднання різних функціональних елементів в єдиний організм. У складі сучасних IHBO слід передбачати різні типи функціональних просторів. В процесі діяльності IНВО окремі функції можуть видозмінюватися i доповнюватися під впливом соціальних вимог i умов ринку. Основним завданням такої інтеграції $є$ створення творчого середовища, яке буде сприяти зародженню, розвитку і впровадженню нових ідей, їх ефективності і конкурентоспроможності, забезпечувати просторовий комфорт співробітників, їх здоров'є і безпеку.

У цих умовах необхідно забезпечити поєднання різноманітних елементів в цілісну структуру, стійкість і ефективність якої заснована на взаємодії складових її елементів. У ІНВО має бути забезпечено взаємодію, обмін інформацією, знаннями між колективами працівників та компаніями. Необхідно включення соціального оточення складовою частиною інфраструктури IHBO - як на рівні генплану, так і в складі будівлі. Продуктивність колегіального спілкування в справі вироблення нових ідей підвищує значущість зон неформального спілкування, відпочинку і спорту, залів для конференцій тощо. Важливими складовими інноваційного процесу є:

- розвиток площ рекламного і виставкового призначення, орієнтованих на залучення клієнтів;

- розвиток об'єктів освіти, призначених для широкого кола зацікавлених осіб.

Підвищення значущості соціального інжинірингу веде до зростання рівня інноваційних досягнень, що визначає максимальний розвиток і використання таких просторів. У сучасному IHBO соціальні простори можуть перевищувати 20\% його площ.

В цілому будь-який IHВО повинен бути орієнтований на вдосконалення формування його архітектурно-містобудівної інфраструктури з урахуванням візуальних якостей середовища (колірний колорит, пластика поверхонь, масштаб об'єктів), що сприймаються людиною. Він повинен мати повноцінне архітектурне середовище (завдяки використанню засобів архітектурної композиції, ландшафтного, міського та світло-кольорового дизайну). [7-10]

Принцип економічності і кооперування дозволяє створити об'єкт з оптимальними витратами. Економічність IHBO $€$ визначальною умовою їх створення. Будівельні економічні рішення дозволяють фірмам-початківцям за допомогою обмеженого венчурного капіталу розгортати інноваційну діяльність. Принцип економічності i кооперування пов'язаний з високою ефективністю всіх інноваційних процесів. Як частина комплексного підходу до формування інноваційного середовища економічність впливає на весь цикл існування об'єкта - проектування, будівництво, експлуатацію та утилізацію. Кількісним параметром оцінки ефективності просторових рішень IHBO є співвідношення величин їх робочої і загальної площі: для нової будівлі 55-60\%, для будівель, що підлежать реновації - 50-55\%. Економічність рішень комплексу підвищується із застосуванням уніфікованих просторових блоківмодулів і будівельних елементів заводського виготовлення.

Для підвищення ефективності інноваційної діяльності необхідно розвиток системи служб кооперованого та дольового використання (допоміжного, технічного, експериментально-модельного, культурно-інформаційного, громадського, соціальнопобутового, спортивно-рекреаційного). Залежно від частоти використання (постійне, періодичне, разове) відповідні служби можуть входити до складу IHBO або розташовуватися в зоні зручного доступу. Додаткові можливості використання перерахованих служб дає виділення в структурі IHВО трьох основних робочих блоків:

- єдиного центру генерування ідей (зони теоретичних офісів головних дослідників);

- загальної дослідницької зони лабораторій для розробки нових ідей;

- загального універсального простору для розміщення важкого, великогабаритного, напіввиробничого обладнання.

У цьому випадку приміщення зв'язані між собою, робочі колективи можуть об'єднуватися. Найбільш повний розвиток отримують служби соціального інжинірингу, а супутні служби можуть бути використані 3 пайовою участю. Розвиток служб кооперованого та дольового використання веде до підвищення ефективності інноваційної діяльності та зниження капітальних і виробничих витрат.

\section{Висновки}

У результаті проведеного дослідження були сформульовані такі висновки:

1. Основними критеріями диференціації IHBO $€$ : вид та профіль діяльності; площа, яку займає об'єкт, особливості його об'ємно-просторової організації, розміщення в межах міської агломерації, характер забудови, умови будівництва і власність. 3 урахуванням викладених критеріїв слід виділити чотири основні типи IHBO: інноваційні центри; бізнес-інкубатори; технопарки; технополіси.

2. Основними принципами формування IHBO $\epsilon$ : інтеграції та реструктуризації; структурного модульного формування; екологічної стійкості та безпеки; соціокультурної і естетичної активізації; економічності і кооперування. 


\section{Література}

1. Агранович Г. М. Реконструкция промышленных предприятий в исторически сложившейся городской застройке / Г. М. Агранович, О. Р. Мамлеев. - Известия вузов. Строительство. - 1996. - №1. - С. 100-104.

2. Вершинин В. И. Эволюция промышленной архитектуры. - Москва : Архитектура-С, 2007. - 210 с.

3. Гетун Г. В. Основи проектування промислових будівель : навч. посібник / Г. В. Гетун. - Київ : Кондор, 2009. - 210 с. 4. Дятков С. В. Архитектура промышленных зданий : учебник / С. В. Дятков, А. П. Михеев. - Москва : Архитектура-С, 2010. - $552 \mathrm{c}$.

5. Типологические основы формирования инновационных зданий в городской среде : монография / О. В. Смирнова ; Харьков. нац. ун-т гор. хоз-ва им. А. Н. Бекетова. - Харьков : ХНУГХ им. А. Н. Бекетова, 2017.- 189 с.

6. Игошев Б. М. История технических инноваций : учебное пособие / Б. М. Игошев, А. П. Усольцев. - Москва : Наука, 2013. $-400 \mathrm{c}$

7. Proctor R.1000 New Eco Designs and where to find them / R. Proctor.-Laurence King c/o Chronicle Books, 2009.-352 p. 8. Wines J. Green Architecture / James Wines. - London: Taschen, 2008. - $240 \mathrm{p}$.

9. Gunshiro Matsumoto. Feature : Greenery landscape // SPADE. - Japan. Farest Design Editors Inc. 2007. - vol.7. - P. 1148.

10. Jodidio Philip. Green architecture Now / Philip Jodidio. Hong Kong, London, Paris, New York : Taschen, 2009. - 416 p.

\section{References}

1. Agranovich, G. M., Mamleev, O. R. (1996). Reconstruction of industrial enterprises in the historically established urban development. News of universities. Building, 1, 100-104.
2. Vershinin, V. I. (2007). Evolution of industrial architecture. Moscow: Architecture-S, 210.

3. Getun, G. V. (2009). Fundamentals of design of industrial buildings. Textbook. manual. Kyiv: Condor, 210.

4. Dyatkov, S. V., Mikheev, A. P. (2010). Architecture of industrial buildings. Textbook. Moscow: Architecture-S, 552.

5. Smirnova O. V. (2017). Typological foundations of the formation of innovative buildings in the urban environment. Monograph. O.M. Beketov National University of Urban Economy in Kharkiv, 189.

6. Igoshev, B. M., Usoltsev, A. P. (2013). History of technical innovations. Textbook. Moscow: Nauka, 400.

7. Proctor, R. (2009). 1000 New Eco Designs and where to find them. Laurence King c/o Chronicle Books, 352.

8. Wines J. (2008). Green Architecture. London: Taschen, 240.

9. Gunshiro M. (2007). Feature : Greenery landscape. SPADE. Japan. Farest Design Editors Inc., 7, 11-48.

10. Jodidio P. (2009). Green architecture Now. Hong Kong, London, Paris, New York : Taschen, 416.

Рецензент: д-р арх., проф. О.О. Фоменко, Харківський національний університет будівництва та архітектури, Харків, Україна

Автор: СМІРНОВА Ольга В'ячеславівна кандидат архітектури, доцент, доиент кафедри Харківський начіональний університет міського господарства імені О.М. Бекетова

E-mail-o.l-y.a@mail.ru

ID ORCID: http://orcid.org/0000-0003-0896-7227

\title{
PRINCIPLES OF THE ARCHITECTURAL ENVIRONMENT OF INNOVATIVE RESEARCH AND PRODUCTION OBJECTS FORMATION
}

\author{
O. Smirnova
}

\section{O.M. Beketov National University of Urban Economy in Kharkiv, Ukraine}

The article is devoted to identifying the features of the architectural environment formation of modern research and production objects and complexes. A clear terminological apparatus has been developed. The definition of the concept "innovative research and production objects and complexes" is defined. It has been determined that innovative research and production objects and complexes contribute to the formation and development of highly effective modern forms of research and production activities, active interaction of partners in research, production, commercial and other spheres, contributing to the spread of innovations, new approaches, new technologies. The formation criteria of innovative research and production objects and complexes have been determined.

Among the main criteria, the author identified the following: by the prevailing type of activity, peculiarities of volumetric-spatial organization, placement within the urban agglomeration, the nature of the building, type of base enterprise.

The article defines the typological characteristics of innovative research and production objects and complexes. The author found that currently the main types of innovative research and production objects and complexes are innovation centers, business incubators, technology parks and technopolises. The article reveals the specifics of the design of innovative research and production objects and complexes. The author determined that the architectural and spatial environment of innovative research and production objects can be represented by a separate building, several buildings or a whole architectural and urban planning complex. Features of shaping of these objects mainly depend on the conditions for the location of there.

The article presents the techniques and basic principles of the formation of the architectural and spatial environment of innovative research and production objects and complexes. The use of these techniques and principles will improve the architectural environment of both existing and new innovative research and production objects. Adapt innovative research and production objects and complexes to the social, functional, technical and aesthetic requirements of people which are changing rapidly.

Keywords: innovations, research and production objects, differentiation, principles. 